\title{
Sensitising the Disadvantaged Groups through Participatory Approaches: IGNOU's Experiences in Madhya Pradesh (India)
}

\author{
Umesh Chandra Pandey (Ph.D.)
}

Regional Director, Indira Gandhi National Open University, Regional Centre, Bhopal (Madhya Pradesh) India

Sarita Chaudhary Ph.D (Pur.)

Assistant Professor, Shree Satya Sai B.Ed College, Karaiwala, Malout, Punjab. India

Shireesh Pal Singh Ph.D. (Ed.)

Centre for Education, School of Informative and Communicative Sciences, Central University of Punjab, Bathinda, India Email: shireeshsingh1982@gmail.com

\section{Doi:10.5901/mjss.2015.v6n5p538}

\begin{abstract}
Madhya Pradesh is home to sizeable proportion of Socio Economically Disadvantaged population of India. Human Development Index of the state is 0.375 which depicts poor socioeconomic conditions. Infant Mortality Rates in some of the areas of the state have been compared to the Sub-Saharan countries as per the World Bank Report titled "India: Achievement and Challenges in Reducing Poverty" It depicts a challenging situation and calls for massive Educational Upliftment of the people working in rural and tribal areas. Government of India has sincerely prioritized these issues through successive five year plans, however the situation on the ground leaves a lot to be desired. Millennium Development Goals (MDGs) have placed renewed emphasis on the capacity building of these communities. India Gandhi National Open University (IGNOU) which is the biggest role player of Open and Distance Learning (ODL) in India has a mandate to bring such disadvantaged groups in to fold of Higher Education. However it has been a challenging job from several points of views as most of the target groups requiring immediate attention are too vulnerable, poorly capacitated to adopt new practices and nearly cut off from the urban centred educational facilities. The areas inhabiting such communities have low penetration of Newspapers, TV or Radios and ODL systems with their paradigmatically different ways of teaching learning are yet to take roots in these areas. It has been a big challenge for IGNOU to reach out to such Disadvantaged Communities, sensitize them through suitable Confidence Building Measures and involve them in the ODL Programmes to strengthen their livelihoods. Despite various initiatives taken up by ministry and other institutions, there is a vacuum of information among the disadvantaged communities. It is now well realised and understood that capacity building systems for such target groups need to be radically different from "Business as Usual Approach". Authors of this paper have the experience of working for the Promotion, Monitoring and Supervision of ODL programmes in these areas. During 2012-13 a series of "Out of Box Approaches" were initiated by the authors for sensitising these communities. Results have been overwhelming with sizeable participation of people from disadvantaged communities. This paper highlights such new participatory approaches to sensitise the communities and results of such interventions. The paper has been divided in to Four Parts. Part-I describes the socio economic conditions of these areas and the constraints by the people in accessing information. Part-Il describes the Confidence Building Measures like "Khula Manch" [Open Interactive Sessions with Community] initiated by the IGNOU Regional Centre Bhopal (Madhya Pradesh) and the response of the communities for such interventions. Part-III describes the initiatives taken by the Regional Centre to sensitise Slum Dwellers in Bhopal. This section also highlights Academic Support Services extended to Slum Dwellers in Slum Areas and the results of such interventions. Part -IV describes the experiences of joint initiatives with "Village Panchayats" in rural areas of District Khandwa in Madhya Pradesh and lastly Part-V describes overall Conclusions and Recommendations.
\end{abstract}

Keywords: Disadvantaged Groups, Participatory Approaches, ODL System

\section{Part I}

\subsection{Need for New Approaches for Community Sensitisation}

The Open and Distance Learning (ODL) system in India has gained prominence among the decision making circles due to its potential to address the perennial issues of Access, Quality, Cost \& Equity in Indian Higher Educational System and 
past few decades have witnessed enormous growth and funding of such institutions. The growing concern for Millennium Development Goals (MDGs) has further strengthened this policy thrust for ODL

The ODL institutions have demonstrated marvellous performance with more than $20 \%$ of enrolment share of Indian Higher Education. It has positively impacted the participation of disadvantaged groups in Higher Education and contributed significantly for India's performance on MDGs. It is now well realised and understood that the emerging systems of Open and Distance Learning (ODL) having a focus on "Innovation and Flexibility" are ideally suited to meet such requirements. Results of ODL interventions have been overwhelming with significant reduction in Cost of Delivery, Growing Students Strength and Enhanced Reach among disadvantaged communities.

Indira Gandhi National Open University (IGNOU), a gigantic institution offering 226 academic programmes, student strength of more than three million and active presence in 43 countries is the biggest role player in ODL scenario of India. Starting with just two courses and about 4,000 students in 1985, IGNOU has now become world's largest mega university, most diverse and inclusive institution. At the international level IGNOU has come up as a Centre of Excellence in the field of Distance Education. University's vision statement reads as follows

"Indira Gandhi National Open University, the National Resource Centre for Open and Distance Learning with international recognition and presence, shall provide seamless access to sustainable and learner-centric quality education, skill up gradation and training to all by using innovative technologies and methodologies and ensuring convergence of existing systems for massive human resource required for promoting integrated national development and global understanding".

Authors of this paper have been involved in the Promotion, Monitoring and Supervision of IGNOU's Student Support Services under the jurisdiction of IGNOU Regional Centre in the capital of Madhya Pradesh. The area is inhabited by significant concentration of Rural Population, Scheduled Tribes, Scheduled Casts and Slum Dwellers etc. One of the authors of this paper had made a query to United Nation's Solution Exchange, an online Knowledge Management Network of Development Practitioners in India thereby seeking information about possible options available for information dissemination in such areas. A detailed account of the possible options available for developmental organisations is given in the report brought out by UN Solution Exchange India [UN Solution Exchange Report-2012]. Some of the important paradigms which emerge out of such discussions are as follows:

a) The local community based organisations should be taken in to confidence and need to be involved in the sensitisation operations. Trusted members of the community should be identified and such people should be sensitised first.

b) We need to develop a layer of locals, well versed with local dialects who can act as conduit between local population and the outside organisation.

c) Local population should act as the co-designer of any products and services through which we intend to serve the community. It will develop a sense of belonging of the community.

The detailed report is available on ftp://ftp.solutionexchange.net.in/public/mf/cr/cr-se-mf-11111101.pdf. The report describes in detail the various facets of the developmental scenario in this area. Another report [UN Solution Exchange Report-2009] which advocates for the deployment of Open and Distance Learning Systems to educate these communities is given on UN Solution Exchange [ICT for Development Community] report available on its web site at: http://www.solutionexchangeun.net.in/ictd/cr/cr-se-ictd-food-08070901.pdf.

The UNDP's fact sheet about Madhya Pradesh highlights the poor Human Development Conditions across the Madhya Pradesh on its web site at: http://www.in.undp.org/content/dam/india/docs/madhyapradesh_factsheet.pdf).

Though IGNOU has been working in this area for a long time, it was observed that the traditional ways of advertising did not evoke expected response from these target groups and enrolment from disadvantaged groups has not been picking up to the desired level. More than $85 \%$ of the enrolment in the entire region came only from the urban centres of four major towns in the state. The representation of huge disadvantaged population living in rural and tribal pockets has been consistently low. The Regional Centre functionaries started with altogether new strategic approach of taking community in to confidence through participatory programmes. It was a radical shift from our earlier approach of relying solely on commercial advertising through newspapers. The rationales for the new approaches lies in the following points:

a) Newspapers have poor penetration in disadvantaged communities and therefore generate poor community response. People show a better response if they are approached through credible individuals/agencies perceived by them as their own. For instance the Community Based Organizations, NGOs and Teachers working at grass roots etc are in a better position to convince them. Moreover people participate 
enthusiastically when they are counseled in group rather than individually. This special feature of the communities prompted us to organize "Khula Manch" (English version of Open Interactive Sessions) with them.

b) Similarly our interventions through Street Plays in Slum Areas and NGO's involvement with Slum Dwellers stimulated encouraging response from them.

c) Our intervention of taking Village Panchayat members in to confidence has stimulated a great deal of interest in villages about our programmes.It strongly advocates for paradigmatically different approach of involving Grassroots Level Institutions in our sensitization drive. This factor was largely ignored in earlier interventions made by the University. The Village Panchayat of one of the village got sensitized to such an extent that they passed a resolution in their general body to collaborate with IGNOU to organize the Students Support Services in their villages. The impact of our interventions has been sustainable and has given rise to spillover effect in rural areas.

\section{Part II}

\subsection{Open Interactive Sessions in Public (Khula Munch)}

KHULA MUNCH is Hind translation of the "Open Interactive Sessions" in which Regional Centre's officials, Academic Counsellors and the Study Centre's functionaries present themselves for grilling and questioning regarding the ODL systems in front of Community Members and Media Persons. Officials respond to the prospective students and their queries over various issues. The idea was to Gain the Public Confidence, Encourage Peer Group Interaction, Redress Students' Grievances, Generate Media \& Civil Society Engagement and to remove the Misconceptions about the Open and Distance Learning systems.

It was felt necessary to hold such sessions because the culture of F2F education is so deep rooted that prospective students find it hard to overcome the psychological barrier to enrol in a paradigmatically new system of education.[Pandey 2001] We felt that to popularise the ODL systems we need to build up confidence for this new system, project ourselves as a system open for public scrutiny and to encourage information dissemination. People from Disadvantaged Communities take a lot of interest in collective counselling sessions because there was no culture of individualised counselling in such communities.

We had the following objectives while conducting KHULA MUNCH Programmes.

\subsection{Confidence Building:}

We strategically approached the communities through Open Interactive Discussions in Public. It helped to remove the psychological barriers with our clientele who were vulnerable and less likely t respond to conventional ways of publicity. We strategically focused on this idea of Openness and Accountability in public to win the confidence of our clientele which was vulnerable and less likely to respond to aggressive marketing methods. The participants were the prospective students, enrolled students, academic counselors and Regional Centre's administrative officials. It was a new experience for the students primarily because the conventional Indian Educational institutions do not have such democratic culture of interaction. The rural students who participated in these sessions were fascinated by such methods. The participatory exercises helped us to build up confidence with the community members. The participants came forward with so many positive suggestions for the improvement in the services which we otherwise did not anticipate.

\subsection{On the spot Guidance/Solution of Problems:}

Prospective students found it interesting to resolve their queries collectively. It helped in one more way. It encouraged more active participation from students and to look for positive solutions in front of media. The Distance Learners generally face the problem of isolation with little or no interaction with their peers. We were surprised to see that participants had several misconceptions for which they could never approach us for clarifications.

\subsection{Motivating new Learners}

Sensitizing the people about IGNOU's activities has been a major challenge particularly in those areas where Open and Distance Learning systems are not well established, we focused on rural teachers because they are in day to day contact 
with our prospective clientele and the rural students make their decisions based on the suggestions given by their teachers. The prospective students and media persons were also invited in these meetings (Pandey and Singh). The rural teachers are the information providers to our prospective target groups and their sense of belonging with our activities helped us to convert them as our brand ambassadors.

\subsection{Identification of problems of existing learners}

The sessions were immensely useful for already enrolled students who attended such sessions. It helped them to meet their Peers, Academic Counselors and Prospective Students and find out a collective solution for their problems in an interactive atmosphere.

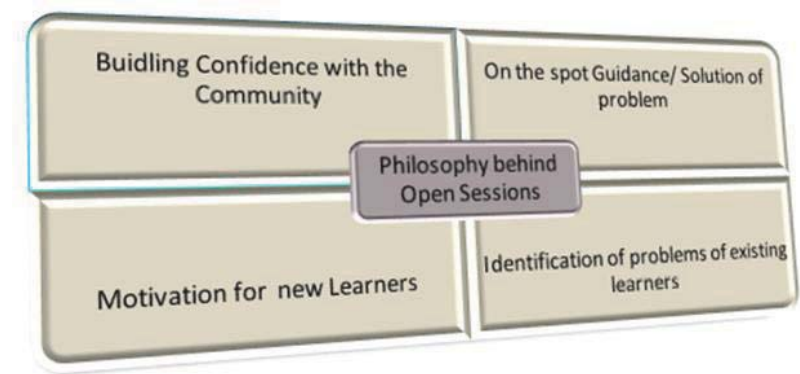

Diagram 1. Philosophy behind Open Sessions

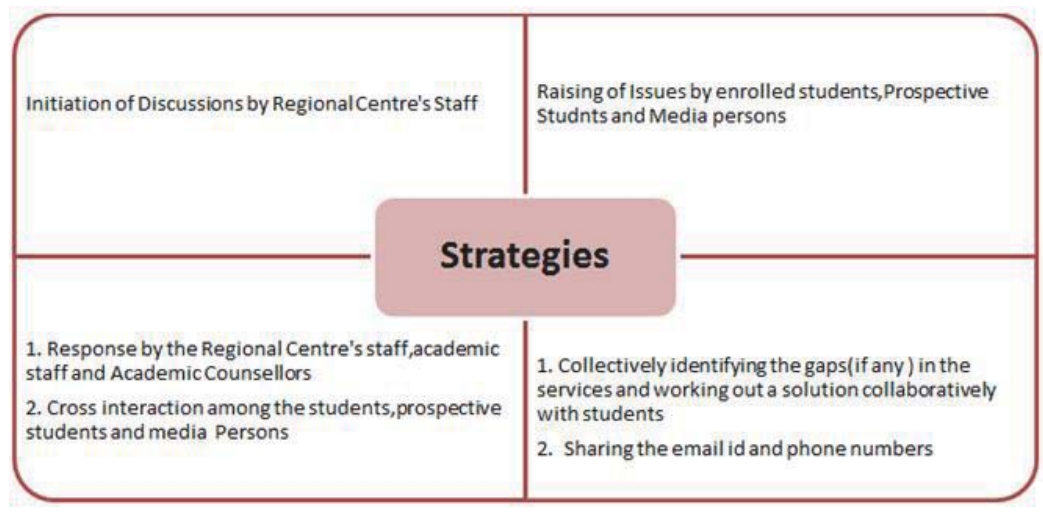

Diagram 2. A schematic Diagram of How a Khula Munch programme Progresses

\subsection{Results and Discussions}

This strategic move worked very well and helped us to win the confidence of the students and media .Result has been overwhelming with sizeable number of SC, ST students taking admission in our programme. The rising trend of enrolment from rural and tribal sector stands testimony to the fact that this approach works well. The exercises were then replicated in several places like Slums, Remote Villages and Central Jails of different cities. Though due to administrative constraints the Media Persons were not invited inside the jails but the jail authorities were present in such interactive sessions. The response of the inmates in the programmes was enhanced several times.

Our experiences through such Khula Munch Programmes have shown the importance of collective counselling. It makes a lot of difference to people from disadvantaged communities. There has been a strong sense of community in these societies which discourages them to come forward for individualised counselling sessions. Such open interactive session's gives rise to a simple but a radically new approach which appealed to these communities so much that they 
voluntarily came forward for holding these programmes. The major observations are as follows

a) The disadvantaged communities show a strong sense of collective decision making. They show a lack of enthusiasm as long as their peers also take similar decisions. Because of their low self-esteem they find it difficult to take decisions but tend to come forward if there is a collective consensus.

b) The prospective students from disadvantaged communities view the experiences of already enrolled students very seriously which forms the basis for their decision making. They rely more on the experiences and opinions of their own community members rather than any outside agency.

Table No. 1: Effect of IGNOU's Open Session on Enrolment of Teachers Professional Development related courses.

\begin{tabular}{|c|l|c|c|c|}
\hline \multirow{2}{*}{ S.No } & \multirow{2}{*}{ Name of The Programme } & \multicolumn{3}{|c|}{ Total Fresh Enrolment } \\
\cline { 3 - 5 } & & $\mathbf{2 0 1 1}$ & $\mathbf{2 0 1 2}$ & $\mathbf{2 0 1 3}$ \\
\hline 1. & Certificate in Guidance (CIG) & 10 & 13 & 124 \\
\hline 2. & Post Graduate Diploma in Educational Management and Administration (PGDEMA) & 2 & 4 & 33 \\
\hline 3. & Post Graduate Diploma in School Leadership and Management (PGDSLM) & 7 & 8 & 9 \\
\hline
\end{tabular}

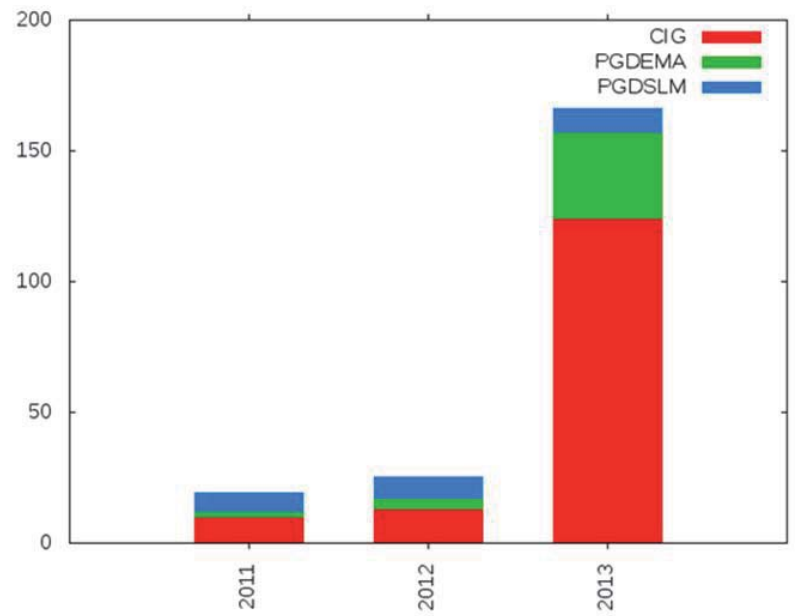

Figure 1: Effect of IGNOU's Open Sessions on Students Response for Teachers Professional Development related courses.

Table No. 2: Effect of IGNOU's Open Session on Enrolment of Prisoners at Central Jail Indore

\begin{tabular}{|c|l|c|c|c|}
\hline \multirow{2}{*}{ S.No } & \multirow{2}{*}{ Name of The Programme } & \multicolumn{3}{|c|}{ Central and District Jail Indore IGNOU special Study Centre (15209) } \\
\cline { 3 - 5 } & $\mathbf{2 0 1 1}$ & $\mathbf{2 0 1 2}$ & $\mathbf{2 0 1 3}$ \\
\hline 1. & Bachelor Preparatory Programme (BPP) & 89 & 27 & 307 \\
\hline 2. & Bachelor Degree (B.A/B.Com) & 14 & 15 & 49 \\
\hline 3. & Certificate Courses. & - & - & 30 \\
\hline
\end{tabular}

Table No. 3: Effect of IGNOU's Open Session on Enrolment of Prisoners at Central Jail Ujjain

\begin{tabular}{|c|l|c|c|c|}
\hline \multirow{2}{*}{ S.No } & \multirow{2}{*}{ Name of The Programme } & \multicolumn{3}{|c|}{ Central Jail Ujjain IGNOU special Study Centre (15211) } \\
\cline { 3 - 5 } & & $\mathbf{2 0 1 1}$ & $\mathbf{2 0 1 2}$ & $\mathbf{2 0 1 3}$ \\
\hline 1. & Bachelor Preparatory Programme (BPP) & - & 83 & 384 \\
\hline 2. & Bachelor Degree (B.A/B.Com) & - & $1-$ & 59 \\
\hline 3. & Certificate Courses. & - & - & 37 \\
\hline
\end{tabular}




\section{Part III}

\subsection{Interventions in Slum Areas of Bhopal}

The consistent migration of the people from rural areas to urban areas has resulted in the large scale development of urban slum population. It has been estimated that $24.31 \%$ of the urban population lives in Slums in Madhya Pradesh.[UNHABITAT Report 2003] These slum dwellers are mostly unskilled and constrained to perform poorly paid jobs. The conventional systems of education due to their rigid delivery systems and costly fee structure cannot meet the educational aspirations of the slum dwellers.[Chugh 2011, Agrawal \& Chugh 2003]]

Though ODL systems have tremendous potential to afford them opportunities of Higher Education we found that it was difficult to make the people realise the importance of education. The traditional ways of advertising have low reach in these communities which made our job difficult. We targeted the school drop outs who wanted to take a second chance to pursue Higher Education. IGNOU has an innovative programme called Bachelor's Preparatory Programme (BPP) which gives the school drop outs direct access to Bachelor Degree Programmes. Any School Drop Out who clears our 6 month bridge programme (BPP) is afforded opportunity to pursue a Bachelor Degree Programme even if S/He has not completed School Education.

We tried to sensitise "School Drop Outs" from Slum Areas through NGOs which were working among the Slum Dwellers. As a first step, special sensitisation programmes were organised for the community workers and they were equipped with information about the ODL systems and the academic programmes [Pandey, Nayak and Mursenia 2013]. Some of the Slum Dwellers were already educated and they were taken in to confidence to communicate with the community and IGNOU's officials. It was difficult to make the people realise the importance of Open and Distance Learning Systems. They had no experience of this new mode of education and it was hard for them to adjust with altogether new kind of educational system.Street Plays were a viable idea to communicate with Slum Dwellers and some of the schools came forward to help us in this regard. Gyan Vani which is a FM Educational Radio of IGNOU at Bhopal turned out to be an added advantage. We organised several radio talks to boost our sensitisation programmes.

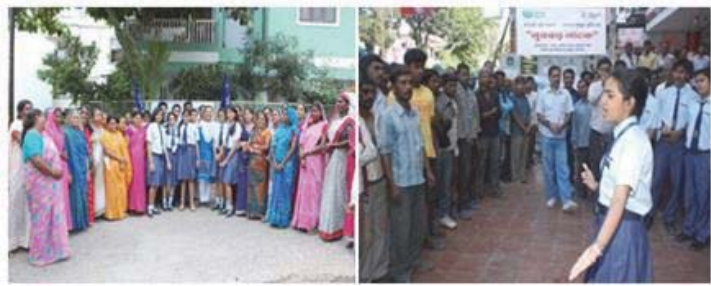

The Street Plays performed by the students mostly drawn from sophisticated schools of Bhopal generated curiosity among the people and they came forward with further queries.

The community response for the programmes of IGNOU was not very encouraging in the initial stage though they came forward with several queries. Mostly married females with age group of 35+ showed a great deal of enthusiasm. We further pursued the desirous students through the community volunteers of NGOs and organised Open Interactive Sessions with them.

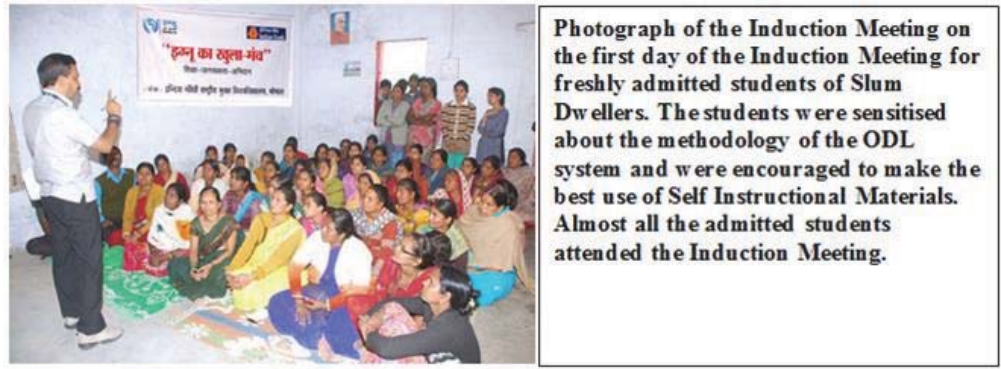

The students were admitted from two clusters in the Slum area of Bhopal. Since all the students were working persons and their livelihoods commitments came first, we planned the schedules for face to face counselling sessions in 
consultation with the students. Scheme of Mobile Study Centre was implemented in the clusters for organising the Academic Support Services jurisdiction right in Slum Areas and at convenient places [Pandey 2012]

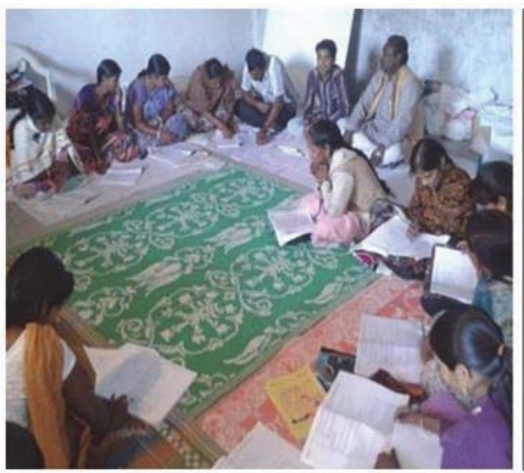

The identification of Academic

Counsellors was difficult as most of the Academic Counsellors were not willing to go to Slum like Conditions for giving counselling. Another issue was that we had to employ only Females as Academic Counsellors. It was required because the most of the students were Females who were not comfortable to take counselling from Male Academic Counsellors.

\subsection{Results and Discussions}

IGNOU's interventions in Slum Areas were taken first time at Bhopal under IGNOU Regional Centre Bhopal. The slum communities have shown encouraging response for the Academic Programmes and has paved the way for the permanent Study Centre for Slum Dwellers. The enrolled students have been very punctual in their assignment submission, attendance in counselling sessions and participated enthusiastically in the counselling sessions. Special counselling sessions were organised through FM Radio run by IGNOU in Bhopal city. The composition of the students group had better representation of the backward cast groups which shows that IGNOU's interventions have been able to take benefits to the neediest person of the Slum Communities. Composition of the students admitted in 2014-15 is as follows:

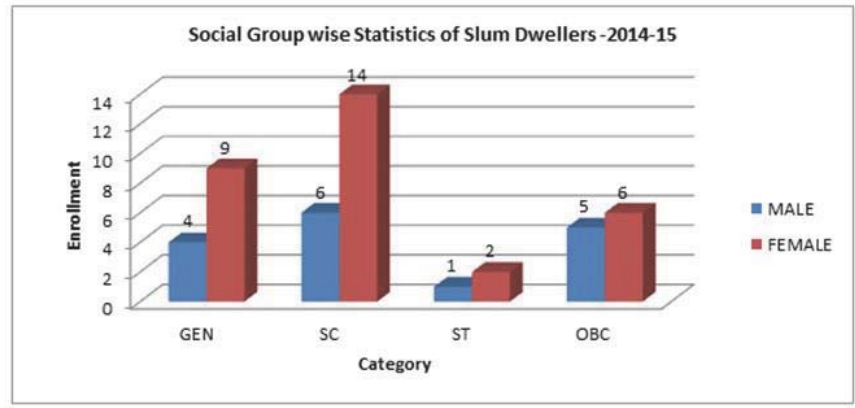

The experience of IGNOU in slum areas gives rise to interesting possibilities of tie ups with Non-Governmental Organisations for Community Sensitisation and Service Delivery in Slum areas. Such possibilities need to be explored for wider participation of Slum Communities in ODL Programmes.

\section{Part IV}

\subsection{Interventions in Rural Areas in Collaboration with "Village Panchayats"}

With increasing policy thrust on the grass root level democracy, Village Panchayats in India are becoming more and more capacitated and empowered to Plan and Implement Developmental Projects. We therefore felt that "Village Panchayats" could be a viable platform to effectively converge with IGNOU's sensitisation operations in rural areas. Our study centre in Khandwa tried out this unique approach to enhance our enrolment base in rural areas [Pandey, Gargava, Patel 2015]. Study Centre followed a proactive approach of motivating Panchayat Members, Elderly Persons in Villages and Teachers 
in the Villages and informed them about how villagers can get benefitted from IGNOU's academic Programmes. They were equipped with information about IGNOU Programmes and Policies and motivated to pass on the information to villagers.
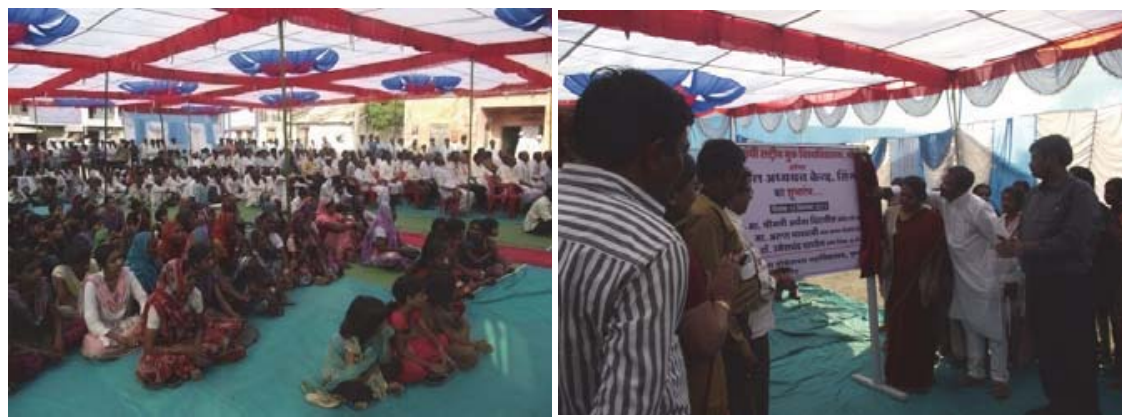

Such an approach was followed because villagers had much greater trust on their community members and leaders. Moreover they speak the same dialect and meet on the platform of Village Panchayats almost regularly. Panchayat Members were also encouraged to pass on the information to villagers during the meetings. The approach worked well and led to trickle down impact on our prospective students. There was significant enhancement in queries about IGNOU's academic programmes and within just one month the enrolment from selected villages went up to 200 for academic programmes on Food \& Nutrition. Coordinator assured the students that if in any cluster of villages a minimum enrolment of 50 is generated then Study Centre will establish a Camp Location in the village itself.

In the first stage Study Centre identified Village-Singot as Camp Location where "Village Panchayat" had passed a resolution to support IGNOU's activities.50 Girl Students from that village had taken admissions in IGNOU programmes. The camp location of IGNOU was set up inside the village to provide Students Support Services. The entire Students Support Services were organised in the village itself and the course completion rates of these students has significantly gone up to $64 \%$. Khandwa Experiment was first tie up of any University in India with grassroots level Community Based Organisation and it was highlighted by the Vice Chancellor-IGNOU as an achievement in Convocation Report of 2014.

\subsection{Results and Discussions}

Our engagement with "Village Panchayats" has unfolded a new approach to work at the grassroots. The involvement of grass root level organisations has proved to be important as the people have a much greater level of trust on their own people, who are drawn from same community setting, speak the same language and meet them on day to day basis. If information is passed on to villagers through such trusted community members then it has a much greater impact on them rather than approaching them directly.

Under the interventions the functionaries of the IGNOU's Study Centre in Khandwa (Madhya Pradesh) aimed at generating a layer of such people who are drawn from village and who are specially oriented to serve the cause IGNOU. The idea was to sensitize such people, equip them with information about IGNOU and take their help in building up a network of Information Services in the villages. This approach was paradigmatically different from the earlier approach of direct advertising to sensitize the community.

It has helped to create a psychological atmosphere which prompted the villagers to come forward for education. Our academic programmes on Food \& Nutrition received encouraging response from rural interiors which was never seen before. Results were overwhelming with one of the village generating enrolment of more than 50 girl students of Food \& Nutrition. Total enrolment from Rural Areas of Khandwa for Food and Nutrition related Academic-Programmes underwent significant enhancement. Members of Village Panchayat in Village- Singot where we had 50 girl students came forward to pass a resolution in General Body Meeting of the Village (Gram Sabha) to support IGNOU's activities and to provide us physical infrastructure for academic counselling. The delivery of academic services in the villages had remarkable positive impact on the participation of students in the counselling sessions and success rate of the students .Our research studies have shown that if properly sensitized, the "Village Panchayats" can prove to be powerful instrument to sensitize the people [Pandey, Smriti \&Patel 2015]. 

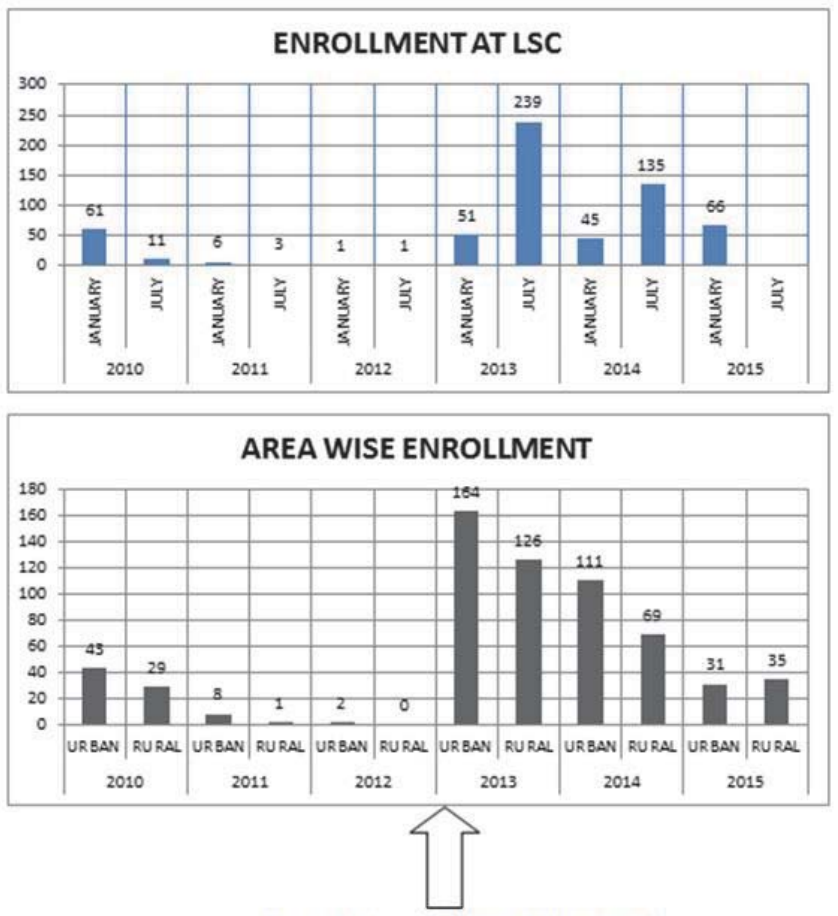

Time when interventions in villages started

\section{PART VI}

\subsection{Conclusions And Recommendations}

The abovementioned engagements with disadvantaged people have shown that Open Universities need to sense the peculiar requirements of the Disadvantaged Communities. Quite often it has been observed that the benefits of the Open University's academic programmes are reaped by only urban population. The Rural people have neither access to the Newspapers nor any technology intensive source of information which again puts them in to a disadvantage. The study centres which are expected to be nerve centres of the information are located in urban areas.

Though Open Universities in India have made significant strides for Disadvantaged Communities, there is immense potential to further enhance reach. In Indian Context Village Panchayats, NGOs and Rural Teachers can be a viable link to connect with Rural Communities. Our experiences tell us that Open Universities should engage with such Community Based Organisations and Individuals to take people in to confidence. We need to develop a layer of such trusted Community Members/Organisations who can act as conduit between Local Population and the Open Universities.

It will not only enhance the participation of people in Higher Education but will also strengthen such Community Based Organisations.

\section{Acknowledgements}

We sincerely acknowledge and thank the team of the IGNOU's Regional Centre Bhopal and its Study Centre at District Khandwa, including officers and administrative staff members who were involved in the community sensitisation activities as described in this paper.

\section{References}

Aggarwal,Y P and Chugh,Sunita (2003). Learning Achievement of Slum Children in Delhi, New Delhi: NUEPA (Unpublished) accessed 
from the web site of NUEPA at http://www.nuepa.org/OccPaper.html on 31st Jan 2014

Amareswaran, N., \& Singh, S. P. (2011). Teacher Education through Open and Distance Learning--Information and Communication Technology Based Pedagogy Integration. Techno LEARN: an International Journal of Educational Technology, 1(1).http://indian journals.com/ijor.aspx?target=ijor:tle\&volume=1\&issue $=1 \&$ article $=005$

Chugh, Sunita (2011). Dropout in Secondary Education: A Study of Children Living in Slums of Delhi, New Delhi: NUEPA (Unpublished), 47 pages accessed from the web site of NUEPA at http://www.nuepa.org/OccPaper.html on 31st Jan 2014

Dangwal, K.\& Singh S. P. (2012). Enhancing spiritualism in virtual world, Turkish Online Journal of Distance Education-TOJDE April 2012 Volume: 13 Number: 2 Notes for Editor-7 http://files.eric.ed.gov/fulltext/EJ983624.pdf

IGNOU's web site at http://www.ignou.ac.in/ accessed on 31st Dec 2014

Pandey, U C (2012) "Evolving a Model for IGNOU's strategic interventions in Rural and Remote areas of Bihar "Published online on Published online in Educational Quest-An International Journal of Education and Applied Social Sciences, Volume 3, Issue 3 http://directory.indianjournals.com/ijor.aspx?target=ijor:eq\&volume=3\&issue=3\&article=014 (Accessed on 11th August 2015)

Pandey, UC and Shireesh Pal Singh (2014) "Reaching out to Disadvantaged groups for Capacity Building through Open and Distance Learning: Experiences of IGNOU Regional Centre Bhopal" International Conference on Education as a Right Across the Levels Challenges, Opportunities and Strategies, organised by Jamia Milia Islamia and UNESCO on 10-11 March 2014 and published in the proceedings of the conference page number 937-948.

Pandey, U C (2012) the concept note on the Mobile Study Centre submitted by Dr U C Pandey (One of the author) to Regional Services Division, IGNOU HQs Maidangarhi New Delhi-68 for mainstreaming the Mobile Study Centre Scheme in the Support Services of IGNOU (Internal official Communication of IGNOU)

Padhan, A., \& Singh, S. P. (2010). Culminating Professional Ethics to Reduce ZPD Gaps in Teacher Education. Learning Community: An International Journal of Education \& Social Development, 1(1).

The challenge of slums": Global Report on Human Settlements, 2003 : A report available on the web site of UN-HABITAT at http://www.unhabitat.org/pmss/listltemDetails.aspx?publicationlD=1156 accessed on 31st Jan 2014

$11^{\text {th }}$ five year plan (2007-2012) available at planning commission web site at http://planningcommission.gov.in/plans/planrel/11thf.htm accessed on 19/06/2008

Minutes of the 93rd Board of Management of IGNOU held at New Delhi held on 07 January 2008.available on IGNOU web site at http://www.ignou.ac.in/bom/mbm.htm accessed on 19/06/2008

Navigating Gender: In development of water and sanitation in Urban areas: A report brought out by the UN-HABITAT. Available on the web at http://www.unhabitat.org/downloads/docs/6745_9802_Navigating_Gender.pdf accessed on 31st Jan 2014

Pandey U. C. 2001 "The evaluation of student support services of IGNOU leading in diversified delivery strategy with special reference to Himachal Pradesh "project report submitted in 2001 under minor research project scheme of IGNOU (INDIA)

Pandey U C, Gargava Smriti, Patel Satish(2015) Exploring the Role of Village Panchayats to Enhance the Outreach in Rural Areas: IGNOU Initiatives in District Khandwa (Madhya Pradesh) in the book titled "Empowering India Through Open and Distance Learning: Breaking Down Barriers, Building Partnerships and Delivering Opportunities" edited by Prof (Mrs) Chandra kantha Jeyabalan, Vice Chancellor Tamil Nadu Open University ,Chennai and Published by Pallavi Sri Publications and Mass Communication Pvt. Ltd ,Page Number 483-487, ISBN : 978-93-81830-89-5

Pandey U.C., Nayak Subash, Mursenia CP,(2013) Enhancing the Educational Opportunities for Slum Dwellers: Experiences of IGNOU Regional Centre Bhopal"Learning Community-An International Journal of Educational and Social Development 4(3) 2013 page 307-315, Available at http://www.indianjournals.com/ijor.aspx?target=ijor:Ico\&volume=4\&issue=3\&article=011 (Accessed on 11 ${ }^{\text {th }}$ August 2015)

Singh, S. P., \&Dangwal, K. (2011). Innovative Practices in Education. New Delhi Publishers., p.145 http://www.sadc.int/files/7213/ 7820/8535/IECStrategyFinalDraftForTranslation06.05.09.pdfhttp://foundationcenter.org/gainknowledge/research/pdf/practicematt ers_07_paper.pdf

U N Solution Exchange (2012) "The Information and Guidance Centres for Rural Poor" query raised by Dr U C Pandey (one of the authors). Report available on web site of UN Solution Exchange at ftp://ftp.solutionexchange.net.in/public/mf/cr/cr-se-mf-1111 1101.pdf (Accessed on 11th August 2015)

World Bank Report titled "India: Achievement and Challenges in Reducing Poverty".Web Site of World Bank at: http://web.worldbank. org/WBSITE/EXTERNAL/TOPICS/EXTPOVERTY/EXTPA/0,,contentMDK:20208959 menuPK:435735 pagePK:148956 piPK:21 6618 -theSitePK:430367,00.html (Accessed on $1^{\text {th }}$ August 2015) 